\title{
MANAJEMEN HUMAS IAIN MADURA DALAM MENARIK MINAT MASYARAKAT
}

\author{
Imam Basofi \\ Pascasarjana Universitas Islam Negeri Maulana Malik Ibrahim Malang \\ imambasofi.insani@gmail.com
}

\begin{abstract}
Abstrak:
Manajemen hubungan masyarakat sangat penting keberadaannya didalam suatu organisasi. Penelitian ini menggunakan pendekatan kualitatif yang dilakukan di Institut Agama Islam Negeri Madura. Teknik pengumpulan data menggunakan teknik wawancara, observasi, dokumentasi. Tahapan analisis data dilakukan dengan penyajian data, reduksi data, dan menarik kesimpulan. Pengecekan keabsahan data melalui meningkatkan ketekunan dan Member check. Hasil penelitian ini; 1. Fungsi manajemen hubungan masyarakat dalam menarik minat masyarakat. (a) perencanaan meliputi, perencanaan fisik, perencanaan fungsional, perencanaan secara luas, dan perencanaan dikombinasikan, (b) pengorganisasian humas dibagi sesuai dengan tupoksi, (c) pelaksanaan hubungan masyarakat, melakukan kerjasama dengan pihak internal dan eksternal kampus, malakukan promosi melalui media massa dan menggunakan peran alumni, (d) evaluasi hubungan masyarakat dilakukan disetiap akhir kegiatan. 2. Pola komunikasi humas, a) internal, melakukan rapat dan musyawarah, b) eksternal, melalui kerjasama, media massa (cetak dan online). 3. Respon stakeholders terhadap humas IAIN Madura, a) respon dosen, b) respon mahasiswa, c) respon tokoh masyarakat.
\end{abstract}

Kata kunci: Manajemen Humas, Minat Masyarakat.

\begin{abstract}
:
Public relations is very important presence in an organization. This study uses a qualitative approach conducted at the Madura State Islamic Institute. Data collection techniques using interview, observation, documentation. Stages of data analysis are performed by presenting data, data reduction, and drawing conclusions. Checking the validity of the data through increasing perseverance and member checking. The results of this study; 1 . The function of public relations management in attracting public interest. (a) planning includes, physical planning, functional planning, broad planning, and combined planning, (b) organizing public relations is divided according to the main tasks and functions, (c) implementing public relations, collaborating with internal and external campus, conducting promotion through media mass and using the role of alumni, (d) evaluation of public relations is done at the end of each activity. 2. Public relations communication patterns, a) internal, conducting meetings and deliberations, b) external, through cooperation, mass media (print and online). 3. Stakeholder responses to the PR IAIN Madura, a) lecturer responses, b) student responses, c) community leaders' responses.
\end{abstract}

Keywords: Public Relations Management, Society Proclivity 


\section{Pendahuluan}

Dewasa ini, lembaga pendidikan dihadapkan pada permasalahan rendahnya minat masyarakat pada lembaga pendidikan. Terutama pada masyarakat di daerah terpencil atau pinggiran, para orang tua kurang memahami pentingnya pendidikan. Mereka lebih mengedepankan bagaimana caranya memperoleh pekerjaan atau menghasilkan uang. Dengan rendahnya minat masyarakat di dunia pendidikan, maka para generasi muda akan menjadi manusia yang kurang akan ilmu pengetahuan.

Perguruan tinggi adalah lembaga satuan pendidikan yang didalamnya melaksanakan proses pendidikan. Perguruan tinggi memiliki peran strategis dalam mencerdaskan kehidupan bangsa, sehingga dituntut untuk terus melakukan perubahan dan perbaikan dalam rangka meningkatkan mutu perguruan tinggi, perguruan tinggi yang kurang cepat dalam merespon perkembangan masyarakat dalam hal ilmu pengetahuan, seni dan teknologi, maka akan ditinggalkan oleh masyarakat. ${ }^{1}$

Perguruan tinggi harus selalu bersinergi dengan masyarakat guna membangun relasi sebagai sebuah upaya untuk memperoleh dukungan masyarakat dalam meningkatkan mutu dan keberhasilan setiap proses pendidikan yang bermuara pada pencapaian tujuan yang diinginkan. Salah satu faktor perguruan tinggi tidak mendapat dukungan dari masyarakat karena tidak mampu mengakomodasi keinginan masyarakat sehingga harapan masyarakat terhadap perguruan tinggi pudar, hal inilah yang akan menjadikan perguruan tinggi stagnan dalam setiap prosesnya karena sudah tidak dipercaya oleh masyarakat.

Selain itu, hubungan masyarakat pada dasarnya merupakan bidang atau fungsi tertentu yang diperlukan setiap organisasi, sebagaimana objek dalam tulisan buku ini adalah lembaga pendidikan.Publik relations, khususnya di lembaga pendidikan pada umumnya disebut hubungan masyarakat (humas). ${ }^{2}$

Keberhasilan suatu organisasi dalam mencapai misi dan tujuannya sangat ditentukan oleh peranan dan kegiatan hubungan masyarakat dalam memelihara hubungan yang harmonis antara lembaga pendidikan dengan masyarakat. Hal ini berarti bahwa lembaga pendidikan merupakan bagian yang tak terpisahkan dari masyarakat, hubungan serasi, terpadu, serta timbal balik yang diciptakan dan dilaksanakan agar peningkatan mutu pendidikan dan pembangunan dapat saling menunjang. ${ }^{3}$

Kegiatan berhubungan dengan masyarakat atau sering disebut humas, pada hakikatnya adalah suatu kegiatan yang pasti dilakukan setiap lembaga, baik lembaga kedinasan, lembaga swasta, lembaga sosial, maupun lembaga ekonomi komersial. Hal itu terjadi karena dalam kehidupan ini manusia selain sebagai makhluk individu juga sebagai makhluk sosial atau makhluk bermasyarakat. Jadi, dimanapun manusia berada, ia selalu berhubungan dengan masyarakat luas, baik masyarakat sekitar maupun masyarakat luas. Hubungan dengan masyarakat dilakukan dengan tujuan memperoleh keuntungan dan kemudahan bagi kedua

\footnotetext{
${ }^{1}$ Syahrizal Abbas, Manajemen Perguruan Tinggi, (Jakarta: Kencana, 2009), hlm. 145

${ }^{2}$ Zulkarnain Nasution, Manajemen Humas di Lembaga Pendidikan. (Malang: UMM Press, 2010), hlm. 9.

${ }^{3}$ Hani Handoko, Manajemen, (Yogyakarta: PT. BPFE, 2003), hlm. 6.
} 
belah pihak. Oleh karena itu, apabila kegiatan humas dilaksanakan dengan baik, pasti menghasilkan suatu kerja sama (partnership) yang baik bagi keduanya. ${ }^{4}$

Humas dalam suatu lembaga pendidikan merupakan rangkaian pengelolaan yang berkaitan dengan kegiatan hubungan lembaga pendidikan dengan masyarakat yang dimaksudkan untuk menunjang proses belajar mengajar di lembaga pendidikan bersangkutan sehingga dapat meningkatkan mutu pembelajaran. Fungsi humas di lembaga pendidikan sesuai dengan Undang-Undang Republik Indonesia nomor 20 tahun 2003 bahwa "Sistem Pendidikan Nasional harus menjamin pemerataan kesempatan pendidikan, peningkatan mutu serta relevansi dan evisiensi manajemen pendidikan untuk menghadapi tantangan sesuai dengan tuntutan perubahan kehidupan lokal, nasional, dan global sehingga perlu dilakukan pembaharuan pendidikan secara terencana, terarah dan berkesinambungan". 5

Sebagaimana yang telah dijelaskan di atas, bahwa humas harus menjadi sebuah sistem yang terencana dengan sebaik-baiknya. Humas di lembaga pendidikan harus dikelola dengan ilmu manajemen yang baik, supaya humas di lembaga pendidikan juga dapat menjalankan fungsinya dengan baik. Adanya peran humas yang baik, maka akan menciptakan humas yang bermutu dan berkualitas, dan akan semakin mempererat humas dengan masyarakat.

Setiap program hanya dapat berjalan lancar apabila mendapat dukungan masyarakat. Oleh karena itu pimpinan perguruan tinggi perlu terus menerus membina hubungan yang baik antara perguruan tinggi dan masyarakat. Perguruan tinggi perlu banyak memberi informasi kepada masyarakat tentang programprogram dan problem-problem yang dihadapi, agar masyarakat mengetahui dan memahami masalah-masalah yang dihadapi perguruan tinggi. Dari pemahaman dan pengertian ini dapat dihadapkan adanya umpan balik yang sangat berguna bagi pengembangan program perguruan tinggi lebih lanjut dan diharapkan pula tumbuhnya rasa simpati masyarakat terhadap program-program perguruan tinggi, yang dapat mengundang partisipasi yang aktif masyarakat.

Perguruan tinggi merupakan salah satu lembaga pendidikan yang didalamnya menyelenggarakan pendidikan tinggi, secara kuantitas perguruan tinggi yangberada di Indonesia mengalami perkembangan hal tersebut adalah wujud dari perkembangan pendidikan nasional, di Indonesia lembaga perguruan tinggi Islam baik yang negeri maupun swasta semuanya 866 perguruan tinggi islam, sebagaimana yang terangkum dalam Data Direktorat Pendidikan Tinggi Islam sebagai berikut; 6

\footnotetext{
${ }^{4}$ B.Suryosubroto, Hubungan Sekolah dengan Masyarakat (School Public Realtions), (Jakarta: Rineka Cipta,2012), hlm. 1.

${ }^{5}$ Undang-Undang Dasar Republik Indonesia No. 20 Tahun 2003 Tentang Sistem Pendidikan Nasional.

${ }^{6}$ Dikutip dari http://diktis.kemenag.go.id/bansos/cari nspt.php, 07/07/2020. 14.08 WIB
} 


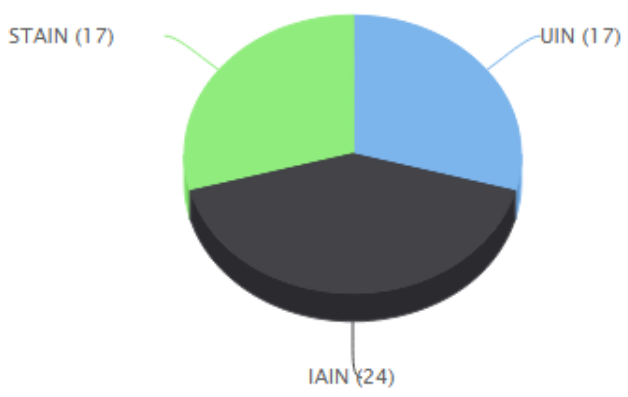

Jumlah Perguruan Tinggi Islam Negeri di Indonesia

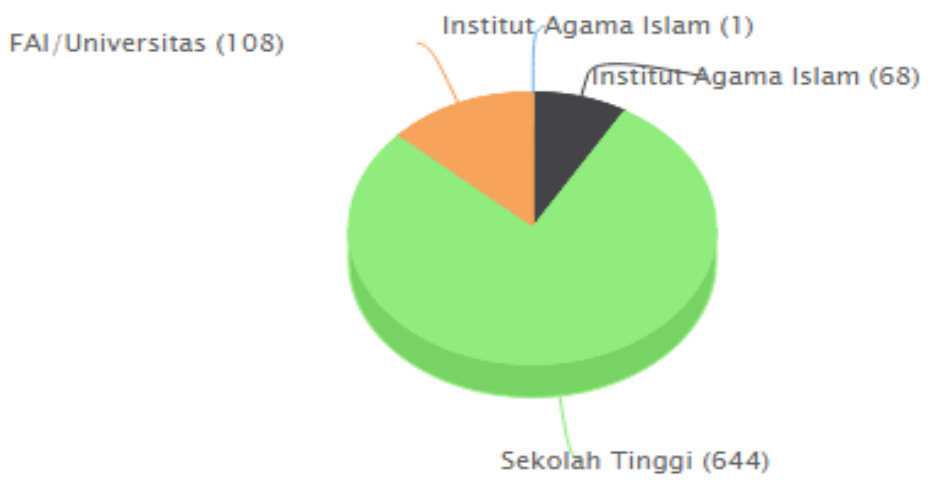

Jumlah Perguruan Tinggi Islam Swasta di Indonesia

Perkembangan jumlah perguruan tinggi tersebut diatas secara kuantitas cukup baik, namun secara kualitas masih banyak perguruan tinggi islam yang harus memacu kualitasnya agar dapat menjadi yang terbaik serta dapat bersaing dikancah nasional dengan berbagai perguruan tinggi yang lain. Diantara indikator kemajuan perguruan tinggi adalah adanya peran masyarakat dan instansi diluar perguruan tinggi untuk meningkatkan mutu, dengan melakukan kerjasama yang baik baik kerjasama edukatif maupun kerjasama yang bersifat kemasyarakatan.

Berdasarkan survey awal yang dilakukan peneliti di IAIN Madura bahwa saat ini IAIN Madura merupakan satu-satunya Perguruan Tinggi Keagamaan Islam Negeri (PTKIN) yang ada di wilayah Madura, sehingga dengan hal inilah yang menjadi daya tarik bagi masyarakat madura, mengingat masyarakat Madura sangat kental dengan nuansa keagamaan, sehingga dalam meilih perguruan tinggi pun masyarakat madura juga menjadikan label lembaga pendidikan keagamaan untuk pendidikan anak-anaknya.

Menurut Kuntowijoyo masyarakat madura merupakan entitas masyarakat yang mengamalkan nilai-nilai keagamaan/Islam. ${ }^{7}$ Sehingga dibidang pendidikan

${ }^{7}$ Kuntowijoyo, Perubahan Sosial dalam Masyarakat Agraris: Madura 1850-1940, (Yogyakarta: Mata Bangsa, 2002), hlm. 328 
pun di Madura banyak lembaga keagamaan, hal ini terlihat dari banyaknya pesantren dan madrasah di Madura. Hal inilah yang menjadi pendukung terhadap bertambahnya minat masyarakat terhadap IAIN Madura, kemudian komunikasi yang dibangun IAIN Madura dengan masyarakat begitu baik sehingga masyarakat memiliki kepercayaan untuk kuliah di IAIN Madura, hal tersebut dibuktikan dengan jumlah calon mahasiswa yang banyak dan meningkat setiap tahunnya, peningkatan tersebut karena ada kepercayaan masyarakat terhadap IAIN Madura.

Berdasarkan survei awal yang dilakukan peneliti di IAIN Madura bahwa saat ini menjadi salah satu perguruan tinggi yang diminati masyarakat. Komunikasi yang dibangun IAIN Madura dengan masyarakat begitu harmonis sehingga kepercayaan masyarakat untuk masuk di IAIN Madurabegitu tinggi, hal tersebut dibuktikan dengan adanya jumlah calon mahasiswa yang cukup banyak, setiap tahunnya pada penerimaan mahasiswa baru mengalami peningkatan yang cukup banyak dibandingkan dari tehun-tahun sebelumnya, peningkatan tersebut tidak lain dikarenakan adanya persepsi positif masyarakat terhadap IAIN Madura. Adapun peningkatan jumlah mahasiswa IAIN Madura sebagaimana tabel berikut:

\begin{tabular}{|c|c|c|}
\hline No & Tahun & Jumlah Mahasiswa \\
\hline 1 & 2017 & 1926 \\
\hline 2 & 2018 & 2175 \\
\hline 3 & 2019 & 2259 \\
\hline
\end{tabular}

Peningkatan Jumlah Mahasiswa IAIN Madura ${ }^{8}$

Data diatas menunjukkan bahwa Antusiasme minat masyarakat terhadap IAIN Madura begitu tinggi, hal tersebut merupakan prestasi yang luar biasa yang harus diapresiasi dan dapat mengindikasikan bahwa IAIN Madura telah mampu menanamkan kepercayaan di khalayak publik, kepercayaan itulah merupakan image positif yang dibangun oleh IAIN Madura dengan berbagai tindakan profesional. Hubungan masayarakat yang dilakukan IAIN Madura memberikan nilai-nilai positif dalam menarik minat masyarakat terhadap institusi.

\section{Metode Penelitian}

Berdasarkan fokus penelitian, obyek penelitian, serta sumber data yang akan dikumpulkan, maka dapat diketahui bahwa penelitian ini termasuk penelitian lapangan (field research), hal ini mendasarkan dari pada penelitian di tengah kancah atau lapangan. ${ }^{9}$ Maka metode yang digunakan dalam penelitian ini adalah metode kualitatif dengan menggunakan pendekatan deskriptif, karena kegiatan penelitian ini akan menghasilkan data deskriptif berupa kata-kata tertulis atau lisan dari orang-orang dan perilaku yang dapat diamati.

Dalam pendekatan deskriptif, data yang dikumpulkan adalah berupa katakata, gambar, dan bukan angka-angka, hal itu disebabkan oleh adanya penerapan metode kualitatif. Dengan demikian laporan penelitian akan berisi kutipan-kutipan data untuk memberi gambaran penyajian laporan tersebut. Data tersebut mungkin

\footnotetext{
8 Data diperoleh dari bagian Bidang Akademik IAIN Madura, (Pamekasan, 11 Mei 2020)

${ }^{9}$ Kartini Kartono, Pengantar Metodologi Riset Social, (Bandung: Mandar Maju, 1996), hal. 47
} 
berasal dari naskah wawancara, catatan lapangan, foto, dokumen pribadi, dan dokumen resmi lainnya.

Hal tersebut bisa mengungkapkan bahwa penelitian ini untuk mendapatkan data atau gambaran yang objektif, faktual, akurat dan sistematis, mengenai masalah yang akan dikaji oleh peneliti. Sehingga penelitian ini dapat dikatakan termasuk jenis penelitian case study yang bertujuan mempelajari secara intensif tentang latar belakang keadaan sekarang dan interaksi lingkungan suatu unit sosial, individu, kelompok, lembaga atau masyarakat. Hal ini seperti yang telah dikatakan Suharsimi Arikunto bahwa: "suatu penelitian yang dilakukan secara intensif, terinci terhadap suatu organisasi, lembaga atau gejala tertentu".10

Secara metodologis penelitian dengan menggunakan jenis case study ini penarikan kesimpulannya tidak hanya mendasarkan pada jumlah individu, akan tetapi pada ketajaman peneliti dalam melihat kecendrungan pola arah, interaksi banyak faktor dan hal-hal lain yang memicu dan menghambat perubahan berdasarkan atas pertimbangan tersebut. ${ }^{11}$

Dengan demikian diketahui bahwa pendekatan yang digunakan dalam penelitian ini adalah pendekatan kualitatif, sebab dalam melakukan tindakan kepada obyek adalah untuk mengetahui makna dari manajemen humas dalam menarik minat masyarakat di IAIN Madura. Dalam penelitian yang dilakukan ini, peneliti menggunakan tindakan kalaboratif partisipatoris yaitu: peneliti bekerja sama dengan stakeholders kampus. Dalam hala ini penliti terjun langsung dalam merencanakan, mengidentifikasi masalah sampai berakhirnya penelitian ini. Dengan demikian kehadiran peneliti dalam penelitian ini mutlak, karena semua kegiatan yang peneliti lakukan selalu bekerja sama dengan semua warga madrasah untuk menentukan langkah-langkah yang harus dilakukan demi lancar dan berhasilnya penelitian ini.

Pada penelitian ini, peneliti mengamati individu atau unit secara mendalam dan mencari faktor-faktor yang dapat menjelaskan kondisi obyek dan obyek yang diteliti. Penelitian kualitatif lebih mengehndaki arah bimbingan penyusunan teori subyektif berdasarkan data baik melalui observasi, wawancara, dan dokumentasi. Jadi penelitian ini bertujuan untuk menyajikan uraian diskriptif tentang bagaimana "manajemen humas dalam menarik minat masyarakat".

\section{Hasil Penelitian}

Pada bagian temuan penelitian ini akan dibahas secara singkat mengenai temuan-temuan penelitian berdasarkan paparan data penelitian yang telah dipaparkan sebelumnya. Adapun temuan pada penelitian akan dibahas dengan menyesuaikan pada fokus penelitian, yaitu sebagai berikut:

Fungsi manajemen hubungan masyarakat dalam menarik minat masyarakat yang dilakukan IAIN Madura adalah mengupayakan setiap fungsi-fungsi humas berjalan dengan baik, peran humas dalam menarik minat masyarakat meliputi: a) memberikan informasi kepada publik atau masyarakat. b) sebagai fasilitator komunikasi antara kampus dengan pihak internal dan pihak eksternal. Adapun

${ }^{10}$ Suharsimi Arikunto, Prosedur Penelitian Suatu Pendekatan Praktek, (Jakarta: Rineka Cipta, 2002), hal. 120

${ }^{11}$ Neong Muhajir, Metodologi Penelitian Kualitatif, (Yogyakarta: Reke Sarasian, 1994), hal. 38 
fungsi manajemen hubungan masyarakat di IAIN Madura adalah seabgai berikut; Perencanaan Humas, Proses perencanaan kegiatan humas dilaksanakan ada yang setiap semester ada yang setiap tahun. Diantara program humas yaitu 1) program kerjasama, meliputi, Pengabdian kepada masyarakat, mengadakan kegiatan keagamaan, mengadakan pertemuan dengan wali mahasiswa, 2) Promosi, meliputi pemanfaatan media massa, pemanfaatan peran alumni.

Pengorganisasian Humas, Pada proses pengeorganisasian di IAIN Madura disesuaikan dengan tugas masing-masing lembaga kampus, sehingga dalam melakukan kerjasama dapat terlaksana secara efektif dan efisien.

Pelaksanaan Humas, Dalam pelaksanaan program humas yaitu dengan, 1) memanfaatkan media massa dengan menyajikan informasi-informasi tentang kegiatan kampus, 2) melakukan pertemuan kerjasama dengan pihak instansi terkait, 3) melakukan kerjasama dengan stakeholders kampus dalam setiap kegiatan.

Evaluasi humas, Evaluasi humas di IAIN Madura dilaksanakan setiap selesai kegiatan. Evaluasi ini berguna dalam memperbaiki program kerja humas dan kemudian akan dilakukan tindak lanjut.

Pola komunikasi dalam hubungan masyarakat di IAIN Madura, sesuai dengan hasil temuan peneliti bahwa sistem komunikasi yang terjadi di IAIN Madura adalah Sistem komunikasi yang terjadi di IAIN Madura adalah a) penyampaian pesan dilakukan atas dasar hasil kebijakan pimpinan kampus melalui musyawarah, b) pesan disampaikan dengan melalui brosur, spanduk, dan media lainnya seperti surat menyurat, media koran, media online dan website IAIN Madura, c) pihak yang menerima pesan atau informasi adalah publik internal dan eksternal IAIN Madura.

Respon stakeholders terhadap humas di IAIN Madura diantaranya adalah respon dari a) dosen IAIN Madura, humas dalam menyampaikan informasi terkait program dan layanan kampus sudah berjalan sesuai fungsinya, b) mahasiswa IAIN Madura, adanya humas sangat memberikan hal positif bagi mahasiswa karena mahasiswa dapat membaca informasi baik di media massa atau media online, c) tokoh masyarakat, kerjasama yang dilakukan bidang pengabdian masyarakat dan kegiatan keagamaan.

\section{Kesimpulan}

Berdasarkan hasil analisis dalam penelitian yang berjudul "manajemen humas dlam menarik minat masyarakat di IAIN Madura". Maka dapat ditarik kesimpulan bahwa manajemen humas dalam menarik minat masyarakat di IAIN Madura, yaitu sebagai berikut:

Manajemen humas dalam menarik minat masyarakat di IAIN Madura. Perencanaan program humas yang meliputi, perencanaan fisik, fungsional, perencanaan secara luas, serta perencanaan yang dikombinasikan. Pengorganisasisan disesuaikan dengan bidang kerjasama yang dilakukan disetiap devisi. Pelakasanaan program humas meliputi, menjalin kerjasama dengan pihak internal dan eksternal kampus demi tercapinya program humas. Evaluasi humas, dilakukan setiap akhir kegiatan.

Adapun pola komunikasi yang dilakukan di IAIN Madura dalam hubungan masyarakat melalui unsur-unsur komunikasi, yang mana penyampaian pesan yang 
dilakukan atas dasar hasil kebijakan pimpinan kampus melalui musyawarah. Pesan disampaikan dengan melalui brosur, spanduk, dan media lainnya seperti surat menyurat, media koran, media online dan website IAIN Madura sebagai media komunikasi. Pihak yang menerima pesan atau informasi adalah publik internal dan eksternal IAIN Madura yang juga sebagai publik yang merespon terhadap apa yang ia terima dari organisas atau perguruan tinggi.

Respon stakeholders terhadap humas di IAIN Madura diantaranya adalah respon dari a) dosen IAIN Madura, humas dalam menyampaikan informasi terkait program dan layanan kampus sudah berjalan sesuai fungsinya, b) mahasiswa IAIN Madura, adanya humas sangat memberikan hal positif bagi mahasiswa karena mahasiswa dapat membaca informasi baik di media massa atau media online, c) tokoh masyarakat, kerjasama yang dilakukan bidang pengabdian masyarakat dan kegiatan keagamaan.

\section{Daftar Pustaka}

Andreas Wato, 2010, Manajemen Hubungan Masyarakat pada Sekolah Inklusi. Studi Multi Kasus pada SMPN 18 dan SMPK Bhakti Luhur Malang, Tesis. Malang, UM.

Arief Kurniawan, 2009, Hubungan Antara Minat Teerhadap Media Pornografi Dengan Intensi Pacaran Pada Siswa-Siswi SMP H.Isriati Semarang Tahun Ajaran 2008/2009, Skripsi Strata Satu, Semarang: Universitas Negeri Semarang.

B.Suryosubroto, 2012, Hubungan Sekolah dengan Masyarakat (School Public Realtions). Jakarta: Rineka Cipta..

Departemen Pendidikan Nasional, 2007, Kamus Besar Bahasa Indonesia, (Jakarta: Balai Pustaka

Djumhur, 1975, Bimbingan dan Penyuluhan di Sekolah. Bandung: CV Ilmu.

H. Abu Ahmadi, 2003, Ilmu Sosial Dasar, Cet. III. Jakarta: Rineka Cipta.

Hadari Nawawi, tt, Penelitian Terapan.Yogyakarta: Gajah Mada University Press.

Hani Handoko, 2003., Manajemen, Yogyakarta: PT. BPFE.

Kartini Kartono, 1996, Pengantar Metodologi Riset Social. Bandung: Mandar Maju.

Koentjaraningrat, 2003, Pengantar Antropologi I, Jakarta: Rineka Cipta.

Lexy J. Meloeng, 2005, Metode Penelitian Kualitatif. Bandung: PT Remaja Rosdakarya.

Lilis Yuliati, 2011,, Jurnal Walisongo (Faktor-faktor yang Mempengaruhi Minat Masyarakat), Volume 19, Nomor 1, Mei.

Morissan, 2008, Strategi Menjadi Humas Profesional. Jakarta: Prenada Media Group. Nasution, 1981, Minat Membaca Sastra Pelajar SMA Kelas III DKI Jakarta. Jakarta Pusat Pembinaan dan Pengembangan Bahasa Depdikbud.

Neong Muhajir, 1994, Metodologi Penelitian Kualitatif. Yogyakarta: Reke Sarasian.

Ngalim Purwanto, 1995, Ngalim Purwanto, Adminiatrasi dan Supervisi Pendidikan. Bandung: PT Remaja Rosda Karya.

Robert Bogdam dan Sari R. Biklen, 1982, Qualitative Resreach for ducation An Introduction to Theory and Methodes. Boston: Allyn and Bacon.

Shaleh Abdul Rahman, Muhbib Abdul Wahab, 2004, Psikologi Suatu Pengantar (Dalam Perspektif Islam). Jakarta: Prenada Media. 
Shintia Sabrina, 2014, Pengelolaan Hubungan Sekolah dengan Masyarakat (Husemas) di SMA Negeri 2 x11 Enam Lingkungn Kabupaten Padang Pariaman, “, Jurnal Administrasi Pendidikan” Volume 2 Nomor 1, Juni.

Suharsimi Arikunto, 2002, Prosedur Penelitian Suatu Pendekatan Praktek. Jakarta: Rineka Cipta.

Susana Aliyannata, 2016, Manajemen Strategi Humas Dalam Promosi Penerimaan Siswa Baru di Madrasah Tsanawiyah Negeri 2 Simo Tahun Pelajaran 2015/ 2016, Tesis. Surakarta: IAIN Surakarta.

Sutrisno Hadi, 1991, Metodologi Research II. Jakarta: Andi Ofset.

Ujang Didi Supriyadi, 2010, Jurnal Ilmu Pendididkan (Pelaksanaan BOS Dan Minat Masyarakat Mengikuti Pendidikan Dasar Gratis), Jilid 17, Nomor 1, Februari.

Undang-Undang Dasar Republik Indonesia No. 20 Tahun 2003 Tentang Sistem Pendidikan Nasional.

Wahid Murni \& Nur Ali, 2008, Penelitian Tindakan Kelas, Pendidikan Agama dan Umum: Disertai Contoh Hasil Penelitian. Malang: UIN Maliki Press.

Wahid Murni, 2008, Cara Mudah Menulis Proposal dan Laporan Penelitian Lapangan, Pendekatan Kualitatif dan Kuantitatif (Skripsi, Tesis, dan Disertasi). Malang: UIN Press.

Wahid Murni, 2008, Menulis Proposal dan Laporan Penelitian Lapangan Pendekatan Kualitatif dan Kuantitatif, Skrispi,Tesis dan Disertasi. Malang: UIN Program Pasca Sarjana.

Yosal Iriantara, 2013, Manajemen Humas Sekolah. Bandung: Simbiosa Rekatama Media.

Zulkarnain Nasution, 2010, Manajemen Humas di Lembaga Pendidikan. Malang: UMM Press. 